\title{
A new metabolic gene signature in prostate cancer regulated by JMJD3 and EZH2
}

\author{
Marine Daures ${ }^{1,2}$, Mouhamed Idrissou ${ }^{1,2}$, Gaëlle Judes ${ }^{1,2}$, Khaldoun Rifaï ${ }^{1,2}$, \\ Frédérique Penault-Llorca ${ }^{2,3}$, Yves-Jean Bignon ${ }^{1,2}$, Laurent Guy ${ }^{2,4}$ and Dominique \\ Bernard-Gallon ${ }^{1,2}$ \\ ${ }^{1}$ Department of Oncogenetics, Center Jean Perrin, CBRV, 63001 Clermont-Ferrand, France \\ ${ }^{2}$ INSERM U1240, IMoST, University Clermont Auvergne, 63005 Clermont-Ferrand, France \\ ${ }^{3}$ Department of Biopathology, Center Jean Perrin, 63011 Clermont-Ferrand, France \\ ${ }^{4}$ Department of Urology, CHU Gabriel Montpied, 63000 Clermont-Ferrand, France \\ Correspondence to: Dominique Bernard-Gallon, email: dominique.gallon-bernard@clermont.unicancer.fr
}

Keywords: prostate cancer; JMJD3; EZH2; gene panel; epidrugs

Received: January 18, $2018 \quad$ Accepted: April 04, $2018 \quad$ Published: May 04, 2018

Copyright: Daures et al. This is an open-access article distributed under the terms of the Creative Commons Attribution License 3.0 (CC BY 3.0), which permits unrestricted use, distribution, and reproduction in any medium, provided the original author and source are credited.

\section{ABSTRACT}

Histone methylation is essential for gene expression control. Trimethylated lysine 27 of histone 3 (H3K27me3) is controlled by the balance between the activities of JMJD3 demethylase and EZH2 methyltransferase. This epigenetic mark has been shown to be deregulated in prostate cancer, and evidence shows H3K27me3 enrichment on gene promoters in prostate cancer.

To study the impact of this enrichment, a transcriptomic analysis with TaqMan Low Density Array (TLDA) of several genes was studied on prostate biopsies divided into three clinical grades: normal $(n=23)$ and two tumor groups that differed in their aggressiveness (Gleason score $\leq 7(n=20)$ and $>7(n=19)$ ). ANOVA demonstrated that expression of the gene set was upregulated in tumors and correlated with Gleason score, thus discriminating between the three clinical groups. Six genes involved in key cellular processes stood out: JMJD3, EZH2, MGMT, TRA2A, U2AF1 and RPS6KA2. Chromatin immunoprecipitation demonstrated collocation of EZH 2 and JMJD3 on gene promoters that was dependent on disease stage. Gene set expression was also evaluated on prostate cancer cell lines (DU 145, PC-3 and LNCaP) treated with an inhibitor of JMJD3 (GSK-J4) or EZH2 (DZNeP) to study their involvement in gene regulation. Results showed a difference in GSK-J4 sensitivity under PTEN status of cell lines and an opposite gene expression profile according to androgen status of cells.

In summary, our data describe the impacts of JMJD3 and EZH2 on a new gene signature involved in prostate cancer that may help identify diagnostic and therapeutic targets in prostate cancer.

\section{INTRODUCTION}

Prostate cancer is the most common male cancer in developed countries, with 758,700 estimated new cases and 307,500 estimated deaths in 2012 [1]. The disease is multifactorial, and includes genetic and environmental risk factors [2,3]. Moreover, prostate cancer is strongly linked to epigenetic alterations resulting in aberrant gene expression [4], particularly with histone methylation, which defines chromatin structure and accessibility to transcription factors $[5,6]$.

Trimethylated lysine 27 of histone 3 (H3K27me3) is a repressive epigenetic mark, and studies show that an aberrant level of it in prostate cancer leads to dysregulation on gene expression [7-9]. H3K27me3 levels are determined by histone methyltransferase EZH2 (enhancer of zeste homolog 2) and histone demethylase JMJD3 (jumonji domain-containing 3), and both these 
proteins are upregulated in prostate cancer [10]. Control of this mark therefore plays a key role in cell integrity, and is a potential biomarker for prostate cancer.

$\mathrm{EZH} 2$, which is the catalytic subunit of polycomb repressive complex 2 (PRC2), plays a predominant role in various cellular processes such as cell cycle regulation and proliferation $[11,12]$. This widely studied protein is shown to have all the oncogene properties, its overexpression stimulating cell proliferation and invasion, but it is also reported in solid prostate malignancies $[13,14]$. Moreover, EZH2 has coactivator functions of a transcription factor by polycomb-independent activity in castration-resistant prostate cancer cells [15].

The first EZH2 inhibitor is DZNeP (3-deazaneplanocin A) and has antitumor activity [16]. This drug inhibits $S$-adenosylhomocysteine hydrolase (SAH), which causes indirect repression of $S$-adenosylmethionine (SAM)dependent histone lysine methyltransferase. Injection of prostate cancer cells pre-treated with $\mathrm{DZNeP}$ in male immunocompromised NOD/SCID mice induced a reduction of tumor formation in $\mathrm{LNCaP}$ and inhibits tumor growth in DU 145 [17]. Furthermore, their treatment with DZNeP shows re-expression of $\mathrm{H} 3 \mathrm{~K} 27 \mathrm{me} 3$-enriched genes $(R A R \beta 2$, $E R \alpha, R G M A$ and $P G R$ ) [9]. These reversible effects are attractive targets for a therapeutic approach.

Histone demethylases are epigenetic actors with a crucial role in cancer by acting as suppressors of tumors or as oncogenes [18]. JMJD3 and UTX (ubiquitously transcribed tetratricopeptide repeat, $\mathrm{X}$ chromosome) are transcription activators, being specific H3K27me3 demethylases. JMJD3 is involved in many cellular process such as development, differentiation, senescence and aging by $\mathrm{p} 16, \mathrm{p} 53$ and RB pathways and finally inflammation [19]. Depending on cancer type, JMJD3 expression is increased (prostate and breast cancers, melanoma, gliomas, renal cell carcinoma [10, 20-24]) or decreased (lung, liver, pancreatic, colon and colorectal cancers [25-27]). This role in carcinogenesis has allowed the development of "epidrugs" to modulate JMJD3 expression.

Several studies have shown that JMJD3 depletion by GSK-J4 chemical inhibitor, an ethyl ester derivative of GSK-J1, could offer a new therapeutic approach in various diseases [28-30], and highlight its anti-tumor activities on brainstem gliomas and breast cancer stem cells in xenograft models $[31,32]$.

A previous study by genome-wide microarrays reported differentially $\mathrm{H} 3 \mathrm{~K} 27 \mathrm{me} 3$-enriched regions in prostate cancer [33]. To understand molecular mechanisms of $\mathrm{H} 3 \mathrm{~K} 27 \mathrm{me} 3$ enrichment and identify new potential gene targets in prostate cancer for improved prognosis and diagnosis, we performed transcriptomic analysis on a TaqMan Low Density Array (TLDA) of selected genes in prostate tissues. We also investigated the impact of EZH2 and JMJD3. First, we performed ChIP-qPCR with JMJD3 and EZH2 antibodies to identify occupancy of both these proteins on gene promoters. Secondly, we identified their effects on gene expressions after pharmacologic inhibition with DZNeP or GSK-J4 treatments.

\section{RESULTS}

\section{Gene set expression is increased in prostate cancer}

To investigate the impact of H3K27me3 enrichment on gene expression [33], and identify potential new actors in prostate cancer, we performed transcriptomic analysis using TaqMan Low Density Array (TLDA) technology on 23 selected genes (Table 1). Gene expression was explored in prostate biopsies representing three clinicopathological groups: a normal group $(n=23)$ and two tumor groups classified according to tumor aggressiveness by their Gleason score (GS): $\mathrm{GS} \leq 7(n=20)$ and $\mathrm{GS}>7(n=19)$.

A heat map representation of RT-qPCR shows increased gene expressions in patients with cancer compared with healthy patients, and related to higher GS (Figure 1A). We thus observed clinicopathological group compartmentalization according to the gene expressions.

To confirm this observation, we performed an analysis of variance (Figure 1B-1D). Figure 1B shows that gene set expression was significantly increased in tumor groups, contrasting with the normal group, and it correlated with GS. An elevated gene expression was observed, consistent with tumor aggressiveness. More precisely, we observed four different expression profiles, but in every case we noted a significant increase in transcriptional expression in tumors with higher GS compared with normal tissues (Figure 1C-1D). The first profile is the most interesting one because gene expression significantly discriminated between the three clinical groups: it includes six genes: JMJD3, EZH2, MGMT, TRA2A, RPS6KA2 and $U 2 A F 1$ (Figure 1C). Figure 1D shows that ING3 expression discriminated both tumor groups compared with the normal group. The third profile distinguished tumors with GS $>7$ from normal tissues, and distinguished intermediate grade tumors (GS $\leq 7$ ) for PAPOLG, SLC4A4, PIK3CB, $P P P 2 R 5 E$ and $S G K 1$. Finally, SGMS1, CNNM2, ESRRG and $K D R$ expressions discriminated tumors with poor clinical prognosis compared with other grades.

Recent studies developed a new set of prostate grade groups, splitting GS $\leq 7$ into three grades: GS $\leq 6$, GS $=3+4$ and $\mathrm{GS}=4+3$ [34]. To validate our classification, we performed the same statistical analysis on group GS $\leq 7$ split into three groups (Figure 2). Results show no significant difference between grades, and so validated our overall classification for the GS $\leq 7$ group.

\section{Loss of gene expression control by JMJD3 and EZH2 in prostate cancer}

To understand the clinical group discriminations by transcriptional expression of $M G M T, T R A 2 A, U 2 A F 1$ and 
Table 1: Gene list designed on TaqMan Low Density Array

\begin{tabular}{|c|c|c|}
\hline Gene symbol & Assay reference & Gene name \\
\hline NMNAT2 & Hs00322752_m1 & Nicotinamide nucleotide adenylyltransferase 2 \\
\hline ESRRG & Hs00976243_m1 & Estrogen-related receptor gamma \\
\hline $\mathrm{CDH} 20$ & Hs00230412_m1 & Cadherin 20 \\
\hline KDM6B & Hs00996325_g1 & Lysine demethylase 6B \\
\hline ING3 & Hs00219444_m1 & Inhibitor of growth family member 3 \\
\hline RXRG & Hs00199455_m1 & Retinoic acid receptor gamma \\
\hline WT1-AS & Hs00274809_s1 & Wilms tumor 1 antisense RNA \\
\hline PPP2R5E & Hs00952135_m1 & Protein phosphatase 2 regulatory subunit B'epsilon \\
\hline EZH2 & Hs00544833_m1 & Enhancer of zeste homolog 2 \\
\hline IRX1 & Hs00411782_m1 & Iroquois homeobox 1 \\
\hline $18 \mathrm{~S}$ & Hs99999901_s1 & - \\
\hline TRIM40 & Hs00373297_m1 & Tripartite motif containing 40 \\
\hline MGMT & Hs01037698_m1 & $O$-6-Methylguanine-DNA methyltransferase \\
\hline PAPOLG & Hs00224661_m1 & Poly(A) polymerase gamma \\
\hline U2AF1 & Hs01597465_g1 & U2 small nuclear RNA auxiliary factor 1 \\
\hline TRA2A & Hs00203263_m1 & Transformer 2 alpha homolog \\
\hline RPS6KA2 & Hs00179731_m1 & Ribosomal protein S6 kinase A2 \\
\hline PIK3CB & Hs00927728_m1 & Phosphatidylinositol-4,5-bisphosphate 3-kinase catalytic subunit beta \\
\hline SGK1 & Hs00985033_g1 & Serum/glucocorticoid regulated kinase 1 \\
\hline KDR & Hs00911700_m1 & Kinase insert domain receptor \\
\hline SGMS1 & Hs00983630_m1 & Sphingomyelin synthase 1 \\
\hline TMPRSS6 & Hs00542184_m1 & Transmembrane protease, serine 6 \\
\hline SLC4A4 & Hs00186798_m1 & Solute carrier family 4 member 4 \\
\hline CNNM2 & Hs00929652_m1 & Cyclin and CBS domain divalent metal cation transport mediator 2 \\
\hline
\end{tabular}

RPS6KA2 and the involvement of JMJD3 and EZH2 in their regulation, we performed a ChIP assay to study their collocation on prostate tissues with the same validated classification: normal $(n=12)$, GS $\leq 7(n=22)$ and $\mathrm{GS}>7(n=6)$.

We demonstrated that EZH2 occupancy on gene promoters was significantly less than JMJD3 irrespective of gene and clinical group (Figure 3A), evoking a possible lower activity of EZH2 compared with JMJD3. This observation supports gene expression results: a higher demethylation inducing transcriptional activation. In detail, if we observed gene expression one by one, this observation was also significantly found for $M G M T$, $U 2 A F 1$ and $R P S 6 K A 2$, but we observed only a trend for TRA2A (Figure 3C-3F).

Furthermore, protein recovery was significantly lower in the intermediate grade $(\mathrm{GS} \leq 7)$ compared with normal tissues, and the same trend was observed for the aggressive tumor group (GS > 7), suggesting a loss of gene expression control by JMJD3 and EZH2 (Figure 3B).

\section{Effects of GSK-J4 on cell viability}

To determine the cytotoxicity of GSK-J4, a chemical inhibitor of JMJD3, three prostate cancer cell lines, DU 145, PC-3 and LNCaP, were treated at increasing concentration for $24 \mathrm{~h}, 48 \mathrm{~h}$ and $72 \mathrm{~h}$. Figure $4 \mathrm{~A}$ shows a considerable concentration-dependent decrease in cell proliferation with treatment. An $\mathrm{IC}_{50}$ study of GSK-J4, exhibited a wide disparity in its concentration according to the cell line: the $\mathrm{IC}_{50}$ values of PC-3 and $\mathrm{LNCaP}$ were $3.53 \mu \mathrm{M}$ and $3.93 \mu \mathrm{M}$ respectively, and conversely was $22.87 \mu \mathrm{M}$ for DU 145.

Finally, we performed a Western blot to verify treatment actions. JMJD3 expression with GSK-J4 treatment was reduced by $61 \%$ for $\mathrm{LNCaP}$ and by around $20 \%$ for DU 145 and PC-3 (Figure 4B). For DZNeP treatment, EZH2 was decreased by $42 \%$ for DU 145 and by around $25 \%$ for LNCaP and PC-3 (Figure 4C).

\section{Impact of JMJD3 and EZH2 on gene regulation}

To highlight the involvement of methyltransferase and demethylase on gene regulation, we performed transcriptomic analysis on prostate cancer cell lines treated and untreated with their inhibitors (GSK-J4 or DZNeP).

Statistical analysis of the cell line effects independent of the treatments showed an opposite expression of the gene set in LNCaP compared with the other cell lines (Figure 5A-5B). Analysis of the combined effects of cell line and treatment also showed that gene set expression was upregulated in DU 145 and PC-3 treated 
with GSK-J4, contrary to LNCaP. We observed the reverse effect for DZNeP treatment (Figure 5C).

More precisely, Figure 5D showed the same profile of gene set expression compared with EZH2 for GSK-J4 treatment by contrast with DZNeP treatment: EZH2 inhibitor treatment leads to a reduction of its expression, with a trend according to cell line aggressiveness, and demonstrated its impact on transcriptional level. JMJD3 expression displays the same distinction between DU 145 and the other cell lines for GSK-J4 treatment, but DU 145 treated with GSK-J4 shows a marked increase in JMJD3 expression.

\section{DISCUSSION}

We began with a transcriptomic analysis on several H3K27me3-enriched genes in prostate cancer. We demonstrated that gene set expression was upregulated in tumors compared with normal tissues and in correlation with Gleason score (Figure 1). In particular, six genes emerged from this study: JMJD3, EZH2, MGMT, TRA2A, $R P S 6 K A 2$ and $U 2 A F 1$.

MGMT is a DNA repair protein, and its DNA hypermethylation has been reported in human cancers [35]. However, a discrepancy in prostate cancer was found. On the one hand, MGMT was shown to be hypermethylated in prostate cancer according to androgen sensitivity and cause a loss of expression [36], but on the other hand, Maruyama et al. found no methylation on this gene, coming closer to our results [37]. A possible explanation of this opposition may lie in ethnic and environmental factors and the disease stage: a meta-analysis in gastric cancer shows heterogeneity on MGMT methylation between Asian and Caucasian populations [38].

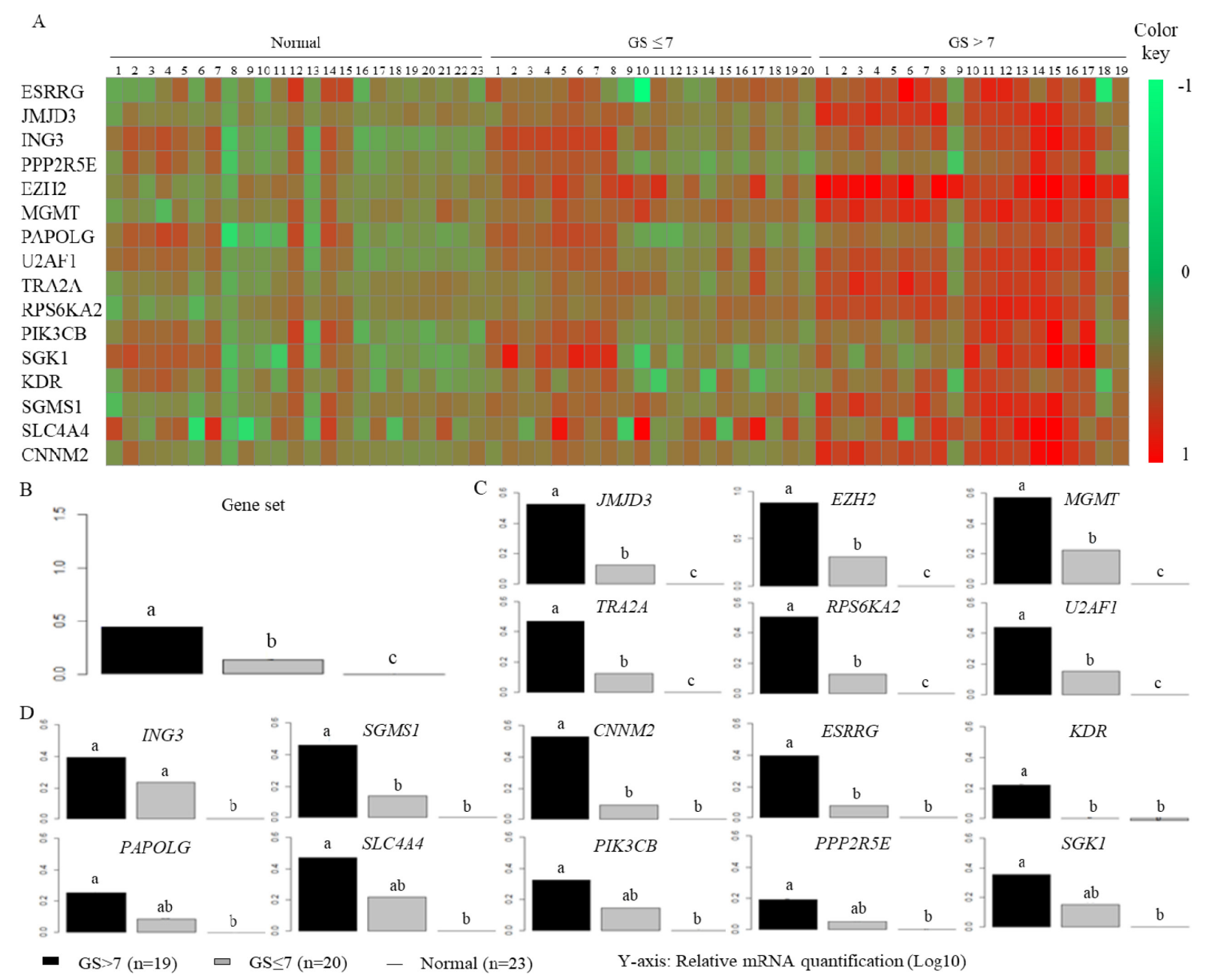

Figure 1: Assessment of gene mRNA expression between clinicopathological groups. mRNA expression was obtained using RT-qPCR by TaqMan Low Density Array (TLDA) in normal tissues ( $n=23$, line) and tumors with different GS: GS $\leq 7$ ( $n=20$, gray bars) and GS $>7$ ( $n=19$ black bars). Representation is the relative mRNA quantification in Log10, and 18S RNA was used as an internal control in the PCR reaction. (A) Representation in heat map format of gene expression. Row represents a gene and column represents clinic groups, each column represents one patient and is illustrated according to a color scale from green to red. (B-D) ANOVA analysis of gene mRNA expression; $y$-axis corresponds to relative mRNA quantification. An analysis of variance followed by a Tukey multiple comparison test designates the statistically significant variables by the letters $a, b$ and $c$. 
Our results support the emergent role of the spliceosome pathway in prostate carcinogenesis [39] with TRA2A and U2AF1: TRA2A is deregulated in different cancers such as hepatocellular carcinoma, pediatric pineal germinomas and triple-negative breast cancer (TNBC) [40-42]. Deregulation of U2AF1 is observed in lung carcinoma [43], and it is mutated in myelodysplastic syndrome [44].

RPS6KA2 (or RSK3), belonging to the RSK (ribosomal S6 kinase) family, is a downstream effector of the Ras/MAPK pathway. Many studies show that deregulation of RSK proteins is associated with cancer development [45], but isoforms have opposite functions: RSK1 and RSK2 are considered as oncogenes, proved in many cancers (breast, lung, leukemia) including prostate, with RSK2-mediated increase in PSA expressions [46] compared with RSK3 and RSK4, but RSK3 activity has been studied only in ovarian and breast cancers [47, 48], and is unknown in prostate tumorigenesis.

Our gene set analysis thus discriminates between the three clinicopathological groups, and highlights genes involved in key cellular processes of carcinogenesis.

We went on to investigate the involvement of JMJD3 and EZH2 on gene regulation. First, we determined the collocation of JMJD3 and EZH2 on MGMT, TRA2A,
RPS6KA2 and U2AF1 promoters suggesting a control of both proteins on their gene regulation (Figure 3 ). Specifically, we identified a lower recovery of EZH2 compared with JMJD3 implying a greater activity of the latter, and so a better demethylation of $\mathrm{H} 3 \mathrm{~K} 27 \mathrm{me} 3$, and a transcriptional activation of target genes. Other studies had shown greater recovery of JMJD3 in contrast to EZH2 on $\mathrm{H} 3 \mathrm{~K} 27 \mathrm{me} 3$-enrichment genes in prostate cell lines [10] and in prostate tissues [49]. These findings confirm the importance of EZH2 and particularly JMJD3 in gene regulation in prostate cancer.

We tested the impact of GSK-J4 and DZNeP, chemical inhibitors of JMJD3 and EZH2 respectively on prostate cancer cell lines. Firstly, we observed a difference in treatment responses with GSK-J4 between DU 145 and other cell lines, PC-3 and LNCaP (Figure 4A). The $\mathrm{IC}_{50}$ was around six times higher for DU $145(22.87 \mu \mathrm{M})$ compared with PC-3 $(3.53 \mu \mathrm{M})$ and $\operatorname{LNCaP}(3.93 \mu \mathrm{M})$. To explain this disparity, the distinction between cell lines was examined. We noted that LNCaP and PC-3 contained a constitutive AKT activity due to an inactivation or loss of PTEN function compared with DU 145, which expressed a functional PTEN protein [50]. Therefore, disparity of GSK-J4 concentration could therefore be explained by
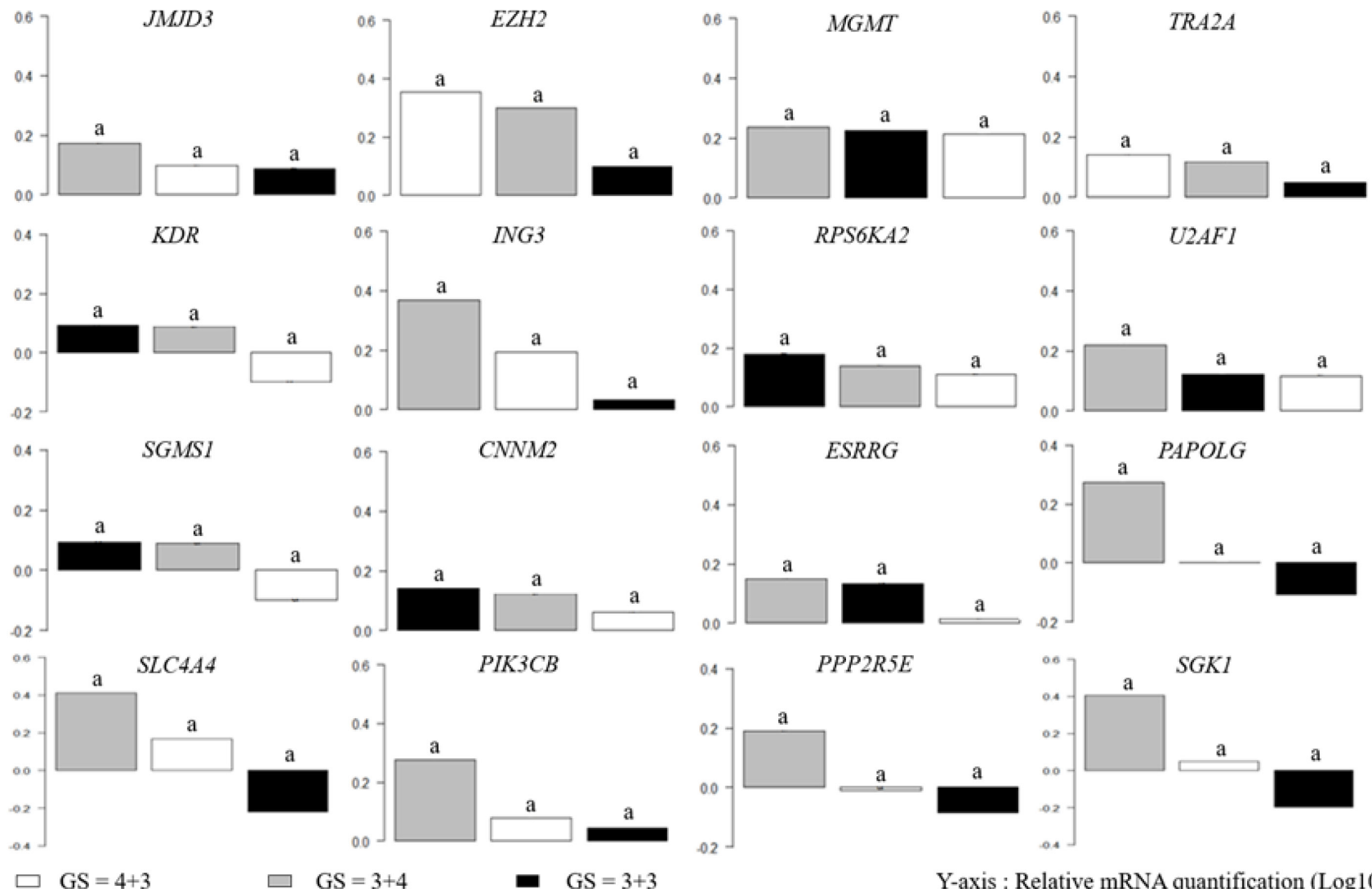

Y-axis : Relative mRNA quantification $(\log 10)$

Figure 2: mRNA expression is not significantly different in GS $\leq 7$ clinicopathological groups. ANOVA analysis was performed on prostate biopsies with $\mathrm{GS} \leq 7(\mathrm{GS}=4+3$ ( $n=11$, white bars), $\mathrm{GS}=3+4(n=7$, gray bars $)$ and $\mathrm{GS}=3+3(n=2$, black bars)); $y$-axis corresponds to relative mRNA quantification in Log10. An analysis of variance followed by a Tukey multiple comparison test was performed. 
their difference in PTEN status, suggesting a possible link between PTEN activity and GSK-J4, and subsequently with JMJD3. PTEN is a tumor suppressor gene involved in the PI3K/AKT pathway, and is inactivated in several cancers including prostate [51]. Interplay between H3K27me3, EZH2 and PTEN is known [52, 53]; H3K27me3 targets and blocks PTEN transcriptional activation. By contrast, only one recent study shows interaction between GSK-J4/JMJD3 and this pathway; GSK-J4 treatment hindered H3K27me3 demethylation, leading to PTEN down-regulation in human monocytic cells [54]. Moreover, the sensitivity difference of GSK-J4 treatment was also observed in correlation with other key pathways of prostate tumorigenesis in castration-resistant prostate cancer cell lines compared with AR-WT prostate cancer cells, suggesting a AR-dependent involvement of JMJD3 [55]. The interplay between JMJD3 and the AR pathway was also evidenced in another study where the transcriptional level of JMJD3 was increased in LNCaP, which are AR-positive, compared with normal
A

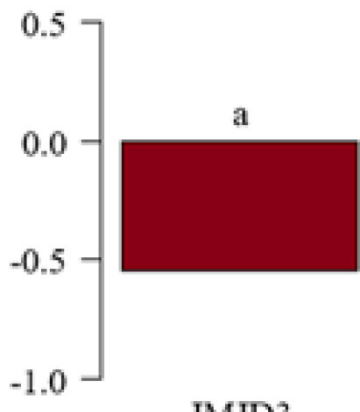

JMJD3

C

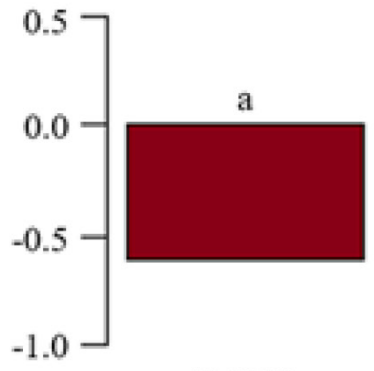

JMJD3

E

$U 2 A F 1$

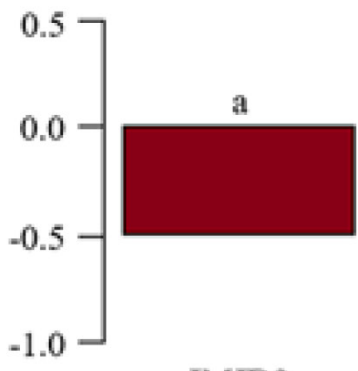

JMJD3
MGMT

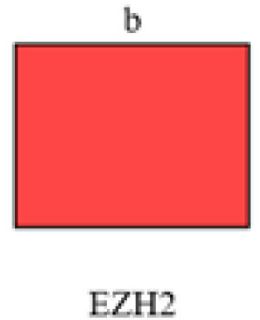

EZH2 b

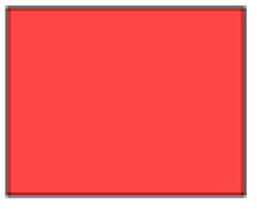

EZH2

\section{B Enrichment according to clinical groups}

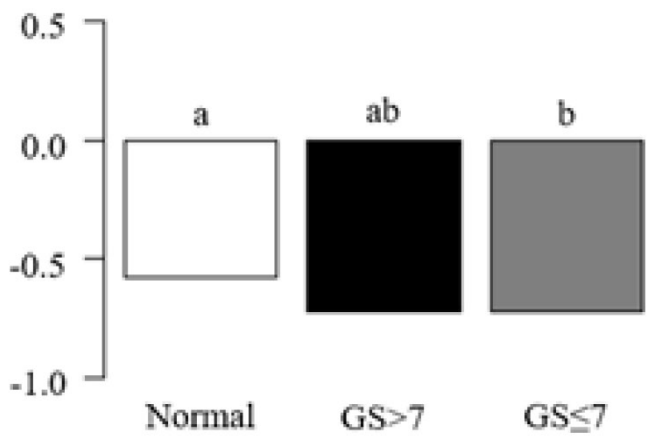

D

TRA2A

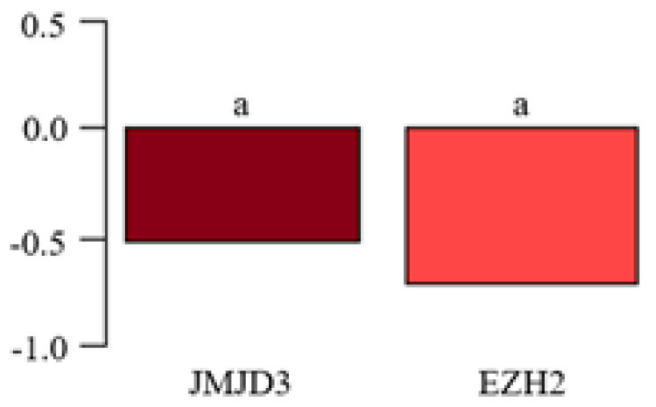

F

RPS6KA2
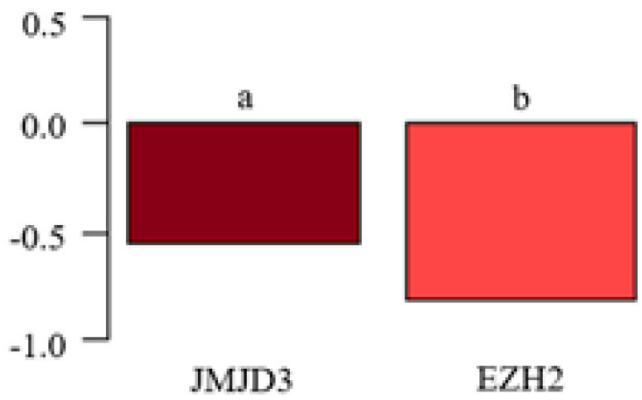

Figure 3: JMJD3 and EZH2 enrichment on MGMT, TRA2A, U2AF1 and RPS6KA2 promoters. ChIP analysis studied the change of JMJD3 and EZH2 on four gene promoters (MGMT, TRA2A, U2AF1 and RPS6KA2) in prostate tumor tissues (GS $\leq 7$ ( $n=22)$ and GS $>7(n=6))$ compared with normal tissues $(n=12) ; y$-axis corresponds to percentage of input in $\log 10$. An analysis of variance followed by a Tukey multiple comparison test designated the statistically significant variables by the letters a and b. (A) EZH2-enrichment was lower compared to JMJD3 throughout promoter gene or clinical groups. (B) Interaction between proteins and genes depends on clinical groups. (C-F) ChIP analysis for individual gene. 
cells (PWR-1E) and AR-negative cells (PC-3) [10]. Our study supports this point, transcriptomic analysis in cells showing an opposition in gene expression in LNCaP (ARpositive) compared with both AR-negative cell lines, PC-3 and DU 145 (Figure 5A, 5C). In the light of these observations, GSK-J4 and DZNeP may be involved in key pathways, PTEN and AR, involved in prostate cancer (Figure 6).

In conclusion, we have identified a gene set modulated by JMJD3 and EZH2. These genes are key components in metabolic pathways involved in prostate cancer, and could be used as potential new biomarkers of prognosis, and also of aggressiveness in prostate cancer. Additionally, the use of epidrug GSK-J4 and DZNeP aimed at demethylase and methyltransferase might enable a new therapeutic strategy to be developed. An in vivo study is now needed to evaluate the impact of treatments on tumor growth, together with gene expression by a xenograft approach like that of Hashizume et al., which demonstrated antitumor activity of GSK-J4 on pediatric brainstem glioma [31].

A
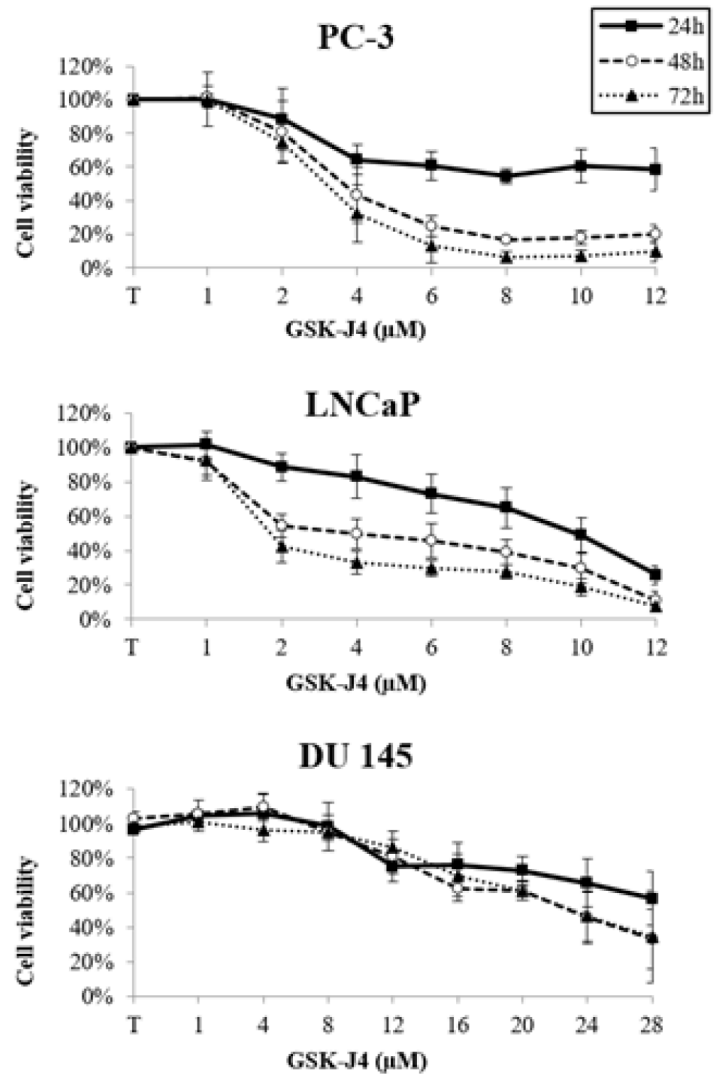

\section{MATERIALS AND METHODS}

\section{Biopsy collection}

Prostate biopsies were obtained from 62 patients for TLDA analysis and 40 patients for ChIP analysis diagnosed by a pathologist at Clermont-Ferrand University Hospital (France). All biopsies were kept in nitrogen. Patients did not receive chemotherapy before clinical examination. All subjects gave written informed consent to the study.

\section{Cell lines and culture conditions}

DU 145, LNCaP and PC-3 were obtained from American Type Culture Collection (ATCC, Manassas, VA, USA) and conserved in liquid nitrogen at the Biological Resource, Jean Perrin Centre. Cells were cultivated in Eagle's minimum essential medium (EMEM) for DU 145 (ATCC), in RPMI 1640 medium for LNCaP (Gibco, Grand Island, NY, USA) and F-12K medium for PC-3 (ATCC). Cultures 
A Gene expression according to cell line

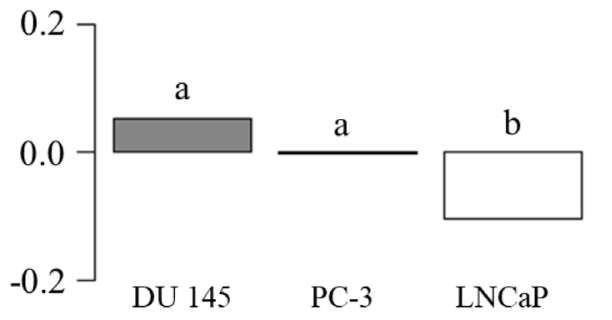

B Gene expression according to treatment

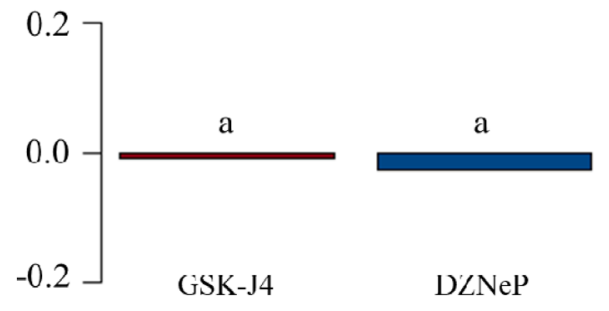

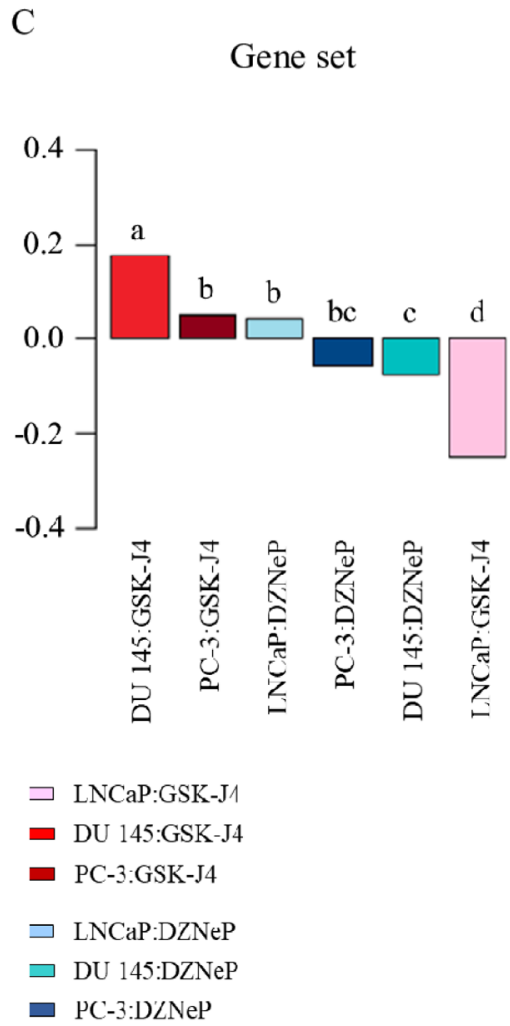

Y-axis : Relative mRNA quantification (Log)
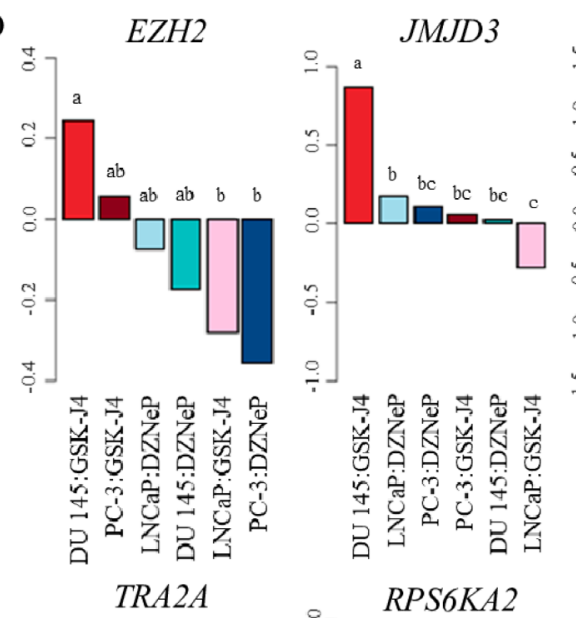

$M G M T$

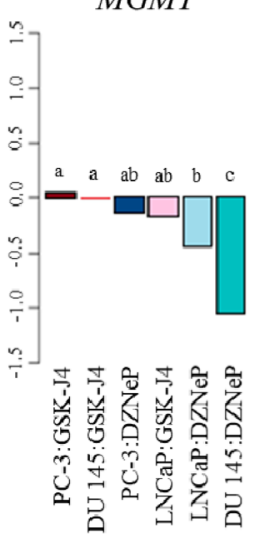

$U 2 A F 1$
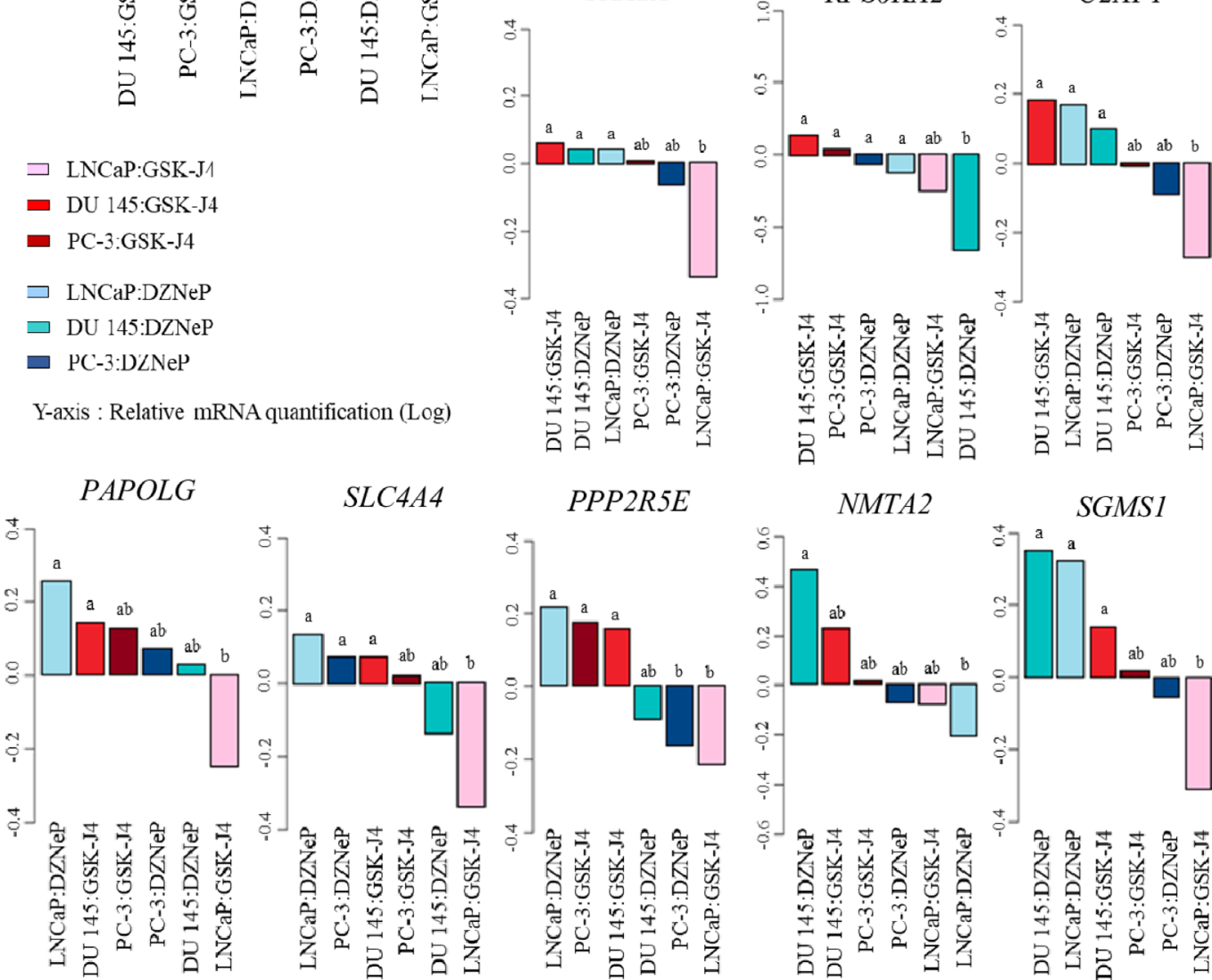

Figure 5: Effects of treatment and cell line on the gene set expression. ANOVA analysis of gene mRNA expression was performed on cell lines (PC-3 (black bars), DU 145 (gray bars) and LNCaP (white bars)) treated with GSK-J4 (neutral bar) or DZNeP (striped bar). Values shown are the average (mean \pm S.E.M) from quadruplicate samples for each incubation condition and normalized to control without treatment; $y$-axis corresponds to relative mRNA quantification in Log. Test designated the statistically significant variables by the letters a, b and c. (A) Gene set expression was different according to cell lines, but (B) not significant according to treatments. (C) Combined effect of cell lines and treatments on whole gene expression. (D) Combined effect of cell lines and treatments gene per gene. 
were supplemented with $10 \%$ heat-inactivated fetal bovine serum (FBS) (Life Technologies, Carlsbad, CA, USA), 1\% glutamine and $0.1 \%$ gentamicin (Panpharma, Luitré, France). Cells were maintained in a monolayer culture at $37^{\circ} \mathrm{C}$ in a humidified atmosphere of $95 \%$ air and $5 \% \mathrm{CO}_{2}$.

\section{Cell viability assay}

Viability assays were performed with an XTT Cell Viability Kit (Biotium, Hayward, CA, USA) according to the manufacturer's protocol. 5000 cells were seeded in sixplicate, and treated with increased doses of GSK-J4 (Sigma-Aldrich, St Louis, MO, USA) for $24 \mathrm{~h}, 48 \mathrm{~h}$ or $72 \mathrm{~h}$. After $2 \mathrm{~h}$ of XTT incubation, cell viability was determined by measuring the absorbance signal at $450 \mathrm{~nm}$ with a Multiskan TM GO Microplate Spectrophotometer (ThermoFisher Scientific). Viable cells were presented as a percentage of the untreated cell control, and $\mathrm{IC}_{50}$ was determined by linear interpolation between concentrations just above and below 50\% inhibition in the response dose curve. $\mathrm{IC}_{50}$ was calculated using the formula: $\mathrm{EXP}(\mathrm{LN}$ (conc $>50 \%)-(($ signal $>50 \%-50) /($ signal $>50 \%$-signal $<50 \%)$ $\mathrm{xLN}($ conc $>50 \% /$ conc $<50 \%))$ ).

\section{Western blotting}

Total protein extractions were performed using RIPA buffer with $1 \%$ protease inhibitor and $1 \%$ phosphatase inhibitor cocktails (Sigma-Aldrich) according to the manufacturer's instructions. Protein concentrations were determined by the Bradford method (Bio-Rad Laboratories, Hercules, CA, USA). $35 \mu \mathrm{g}$ of all protein samples were separated on 4-15\% Mini-PROTEAN ${ }^{\circledR}$ TGX $^{\mathrm{TM}}$ Precast Protein Gels (Bio-Rad Laboratories) and transferred to nitrocellulose membranes (Bio-Rad Laboratories).

Membranes were blocked for $1 \mathrm{~h}$ at room temperature with $5 \%$ milk in TBST buffer (1X Trisbuffered saline, $0.1 \%$ Tween). Primary antibodies used were: anti-EZH2 (1:500, \#C15410039, Diagenode, Seraing, Belgium) anti-JMJD3 (1:750, \#ab169197, Abcam, Cambridge, UK) and anti-GAPDH (1:5000, \#sc-25778, Santa Cruz Biotechnologies, Dallas, TX, USA). After three washes, membranes were blocked with secondary antibody anti-rabbit ads-HRP (1:5000, \#405005, Southern Biotech, Birmingham, AL, USA).

Membranes were incubated in ECL Clarity Western Substrate (Bio-Rad Laboratories) and detection was performed on a ChemiDoc ${ }^{\mathrm{TM}}$ Touch Imaging System (Bio-Rad Laboratories) coupled with Image Lab ${ }^{\text {TM }}$ Touch Software; quantification was expressed as the ratio of proteins over GAPDH densities.

\section{Quantitative real-time PCR}

\section{RNA extraction}

Biopsies were disrupted in nitrogen solution with a French press. Total mRNA isolation was performed using an RNeasy Micro kit (Qiagen, Crawley, UK) according to

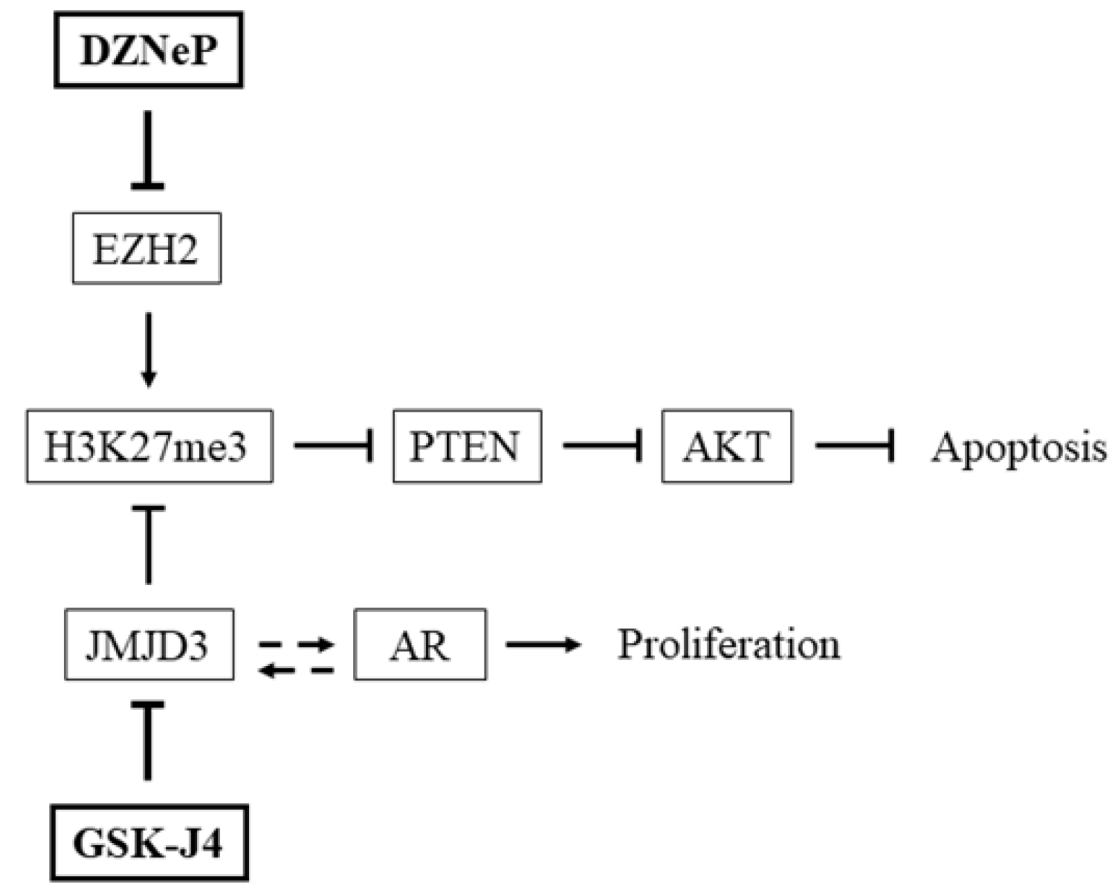

Figure 6: Interaction of GSK-J4 and DZNeP on PTEN and AR pathways. Effects of JMJD3 and EZH2 inhibitors on key pathways involved in prostate cancer. JMJD3 inhibitor GSK-J4 enhanced H3K27me3 which inhibited PTEN expression and activated AKT; by contrast, DZNeP counteracted these effects. GSK-J4 acts on AR-driven transcription and interferes with proliferation. Arrows indicate an activation, blocked arrows indicate an inhibition and dotted arrows a presumed interaction. 
the manufacturer's instructions, and RNA was eluted in 10 $\mu l$ of RNase-free water.

For GSK-J4 treatment, cells were plated in T75 at a density of $1 \times 10^{6}$ cells with $\mathrm{IC}_{50}$ concentration (PC-3: $3.53 \mu \mathrm{M}$, LNCaP: $3.93 \mu \mathrm{M}$ and DU 145: $22.87 \mu \mathrm{M})$ and for DZNeP treatment cells were plated in 6-well plates at $0.5 \times 10^{5}$ cells with $10 \mu \mathrm{M}$ of DZNeP [9]. After $48 \mathrm{~h}$ of GSK-J4 treatment or $72 \mathrm{~h}$ of DZNeP treatment, cells were washed in phosphate-buffered saline (PBS, Life Technologies), and total mRNA isolation was performed using a TRIzol ${ }^{\circledR}$ Plus RNA Purification kit (Invitrogen, Carlsbad, CA, USA) according to the manufacturer's protocol; RNA was eluted in $50 \mu \mathrm{L}$ of RNase-free water.

Final RNA concentration and purity were measured using a NanoDrop ND-8000 spectrophotometer (NanoDrop Technology, LabTec).

\section{Reverse transcription}

$1 \mu \mathrm{g}$ of total mRNA per sample was reversetranscribed in $20 \mu \mathrm{L}$ total volume using a High Capacity cDNA Reverse Transcription kit (Applied Biosystems, Foster City, CA, USA) according to the manufacturer's instructions. Incubation was at $25^{\circ} \mathrm{C}$ for $10 \mathrm{~min}$, reverse transcription was at $37^{\circ} \mathrm{C}$ for $120 \mathrm{~min}$, and inactivation was at $85^{\circ} \mathrm{C}$ for $5 \mathrm{~min}$.

\section{qPCR using TaqMan Low-Density Array (TLDA)}

24 gene expressions (Table 1) were quantified using a custom-made TLDA, which was a 384-well microfluid card (Applied Biosystems). This microfluid card can run 8 duplicate samples against 24 TaqMan Gene Expression Assay targets that are preloaded into each card well. 18S RNA was used as an internal control in the PCR reaction. $100 \mathrm{ng}$ of cDNA was mixed with TaqMan Universal PCR Master Mix (Applied Biosystems). Samples were transferred into the sample-loading port of the TLDA and centrifuged twice for $1 \mathrm{~min}$ at $1200 \mathrm{rpm}$. TLDA was sealed to prevent contamination between wells. qPCR was performed, and cDNA was quantified with the TaqMan method (ABI Prism 7900 HT Sequence Detection System, Applied Biosystems) according to the manufacturer's instructions. Threshold cycle $(\mathrm{Ct})$ higher than 35 as the threshold of non-expressed gene. The relative quantification (RQ) of gene expression was determined using the comparative $\Delta \Delta \mathrm{Ct}: \mathrm{RQ}=2^{-\Delta \Delta \mathrm{Ct}}$ with $\Delta \mathrm{Ct}=\mathrm{Ct}$ (target gene) - $\mathrm{Ct}$ (endogenous gene 18S) and $\Delta \Delta \mathrm{Ct}=\Delta \mathrm{Ct}$ (tumoral group) - $\Delta \mathrm{Ct}$ (normal group) in patient study or $\Delta \Delta \mathrm{Ct}=\Delta \mathrm{Ct}$ (treated cells) - $\Delta \mathrm{Ct}$ (untreated cells) for in vitro study.

\section{Chromatin immunoprecipitation (ChIP)}

\section{Chromatin extraction and sonication}

To optimize cofactor fixation on DNA, tissues were incubated with $0.4 \%$ ChIP cross-link Gold (Diagenode) in
$\mathrm{PBS} / \mathrm{MgCl}_{2}$ (PBS with $1 \mathrm{mM} \mathrm{MgCl}$ ) for $30 \mathrm{~min}$ at room temperature. After washing in PBS/PIC (Protease Inhibitor Cocktail), samples were incubated with $1 \%$ formaldehyde (Sigma-Aldrich) for $5 \mathrm{~min}$ at room temperature. Crosslinking was stopped with $0.125 \mathrm{M}$ glycine for $5 \mathrm{~min}$ at room temperature. After washing, samples were centrifuged for $2 \mathrm{~min}$ at $8000 \mathrm{~g}$ and resuspended in lysis buffer (5 mM PIPES pH 8, 85 mM KCL, 0.5\% IGEPAL, $\mathrm{PIC}$ ) in ice for $15 \mathrm{~min}$. Lysates were centrifuged for $2 \mathrm{~min}$, $10,000 \mathrm{~g}$ at $4^{\circ} \mathrm{C}$, and pellets were incubated in lysis buffer tL1 (Diagenode) for $5 \mathrm{~min}$ in ice.

After adding 3 volumes of HBSS+PIC, samples were sonicated with a Bioruptor ${ }^{\mathrm{TM}}$ sonicator (Diagenode) for $10 \mathrm{~min}(10$ cycles, $30 \mathrm{~s} \mathrm{ON} / 30 \mathrm{~s} \mathrm{OFF})$ at $4^{\circ} \mathrm{C}$. Lysates were clarified by centrifugation $\left(10 \mathrm{~min}\right.$ at $\left.14,000 \mathrm{~g}, 4^{\circ} \mathrm{C}\right)$, and supernatants were transferred to new tubes.

Before analysis, the efficiency of incubation time and sonication was checked by DNA extraction and migration on $1.5 \%$ agarose gel (Supplementary Figure 1).

\section{Chromatin immunoprecipitation}

Chromatin immunoprecipitation was performed using an AUTO True MicroChIP KIT (Diagenode) according to the manufacturer's protocol on an SX-8G IP-Star ${ }^{\circledR}$ Compact Automated System (Diagenode). ChIP used $200 \mu \mathrm{L}$ of sonicated chromatin and $3 \mu \mathrm{g}$ of antibodies: anti-H3K27me3 (\#C15410069, Diagenode), anti-EZH2 (\#C15410039, Diagenode), anti-JMJD3 (\#ab85392, Abcam) and anti-IgG for negative control (\#C15410206, Diagenode). Antibody coating reaction with protein A-coated magnetic beads lasted $3 \mathrm{~h}$, and the immunoprecipitation reaction $13 \mathrm{~h}$ at $4^{\circ} \mathrm{C}$. Reverse cross-linking was carried out for $4 \mathrm{~h}$ at $65^{\circ} \mathrm{C}$.

Immunoprecipitated DNA (IP) and total DNA (input) were purified by MicroChIP DiaPure columns (\#C03040001, Diagenode) according to the manufacturer's instructions, and analyzed by real-time PCR.

\section{Real-time PCR}

qPCR was performed in triplicate at $25 \mu \mathrm{L}$ final reaction volume $\left(5 \mu \mathrm{L}\right.$ of IP or input, $1 \mathrm{X}$ de TaqMan $^{\circledR}$ Universal PCR Master Mix (Applied Biosystems), $400 \mathrm{nM}$ for each forward and reverse primers (SigmaAldrich), $250 \mathrm{nM}$ of probe (Applied Biosystems) (Table 2) and $4.25 \mu \mathrm{L}$ of water) on a 7900 HT Fast Real Time PCR System (Applied Biosystems).

The recovery level of proteins was disclosed by the rate of IP relative to Input. The efficiency of chromatin immunoprecipitation of a particular genomic locus can be calculated from qPCR data and reported as a percentage of starting material: $\%(\mathrm{ChIP} /$ Total Input $)=2^{\wedge}[(\mathrm{Ct}(x \%$ input $)$ $\left.\left.-\log \left(x^{\%} /\right) / \log 2\right)-\mathrm{Ct}(\mathrm{ChIP})\right] \times 100 \%$. Ct (input) and $\mathrm{Ct}$ (ChIP) are threshold values obtained from the exponential phase of qPCR for the immunoprecipitated DNA sample and input sample respectively. $\log (x \%) / \log 2$ accounted for the dilution $1 / x$ of the input. Before analysis, we checked 


\begin{tabular}{|c|c|c|}
\hline Gene & Sequence primers & MGB probes \\
\hline$M G M T$ [7] & $\begin{array}{l}\text { F: AAAGGTACGGGCCATTTGG } \\
\text { R: GGCGCCTTCCCAGCTT }\end{array}$ & TAAGGCACAGAGCCTC \\
\hline RPS6KA2 & $\begin{array}{l}\text { F: GGAGATAGACATCAGCCATCATGT } \\
\text { R: AGCTCAAACTGGGAAGGATCTG }\end{array}$ & AAGGAGGGCTTTGAGAAG \\
\hline$T R A 2 A$ & $\begin{array}{l}\text { F: CTTCGTGAAGTATGTTCTTGATATGGA } \\
\text { R: GCCCAGTTTGCTGGTTGTAAA }\end{array}$ & CTTTGAATGGTGCCAATG \\
\hline$U 2 A F 1$ & $\begin{array}{l}\text { F: GAGCATGTCGTCATGGAGACA } \\
\text { R: GGTCTGGCTAAACGTCGGTTT }\end{array}$ & TGCTCTCGGTTGCACAA \\
\hline
\end{tabular}

Primer and probe sequences were selected with the help of Primer Express software (ABI).

the presence of proteins by the fold-enrichment on gene control TSH2B and GAPDH (Supplementary Figure 2).

\section{Statistical analyses}

Statistical analyses were performed using R 3.0.3 software. All data followed a normal distribution, verified by four tests, namely Kolmogorov-Smirnov, Cramer-von Mises, Lilliefors and Anderson-Darling; if the distribution was abnormal, a one-parameter Box-Cox transformation was used. Data were analyzed with an ANOVA to test significant difference in gene expression average between clinicopathological groups in the patient study, between treatments and cell lines in the in vitro study and between genes occupancy in ChIP study. Multiple comparisons were carried out with a Tukey's post hoc test; statistical significance was set at $p<0.05$.

\section{ACKNOWLEDGMENTS}

The authors thank the Hariri Foundation for providing grant support to Khaldoun Rifaï.

\section{CONFLICTS OF INTEREST}

The authors declare they have no conflicts of interest

\section{GRANT SUPPORT}

This work was supported by grants from the French Ligue Régionale Contre le Cancer - Comités du Puy-deDôme et de la Haute-Loire, and from ARTP (Association pour la Recherche sur les Tumeurs de la Prostate).

\section{REFERENCES}

1. Torre LA, Bray F, Siegel RL, Ferlay J, Lortet-Tieulent J, Jemal A. Global cancer statistics, 2012. CA Cancer J Clin. 2015; 65:87-108.

2. Adjakly M, Ngollo M, Dagdemir A, Judes G, Pajon A, Karsli-Ceppioglu S, Penault-Llorca F, Boiteux JP,
Bignon YJ, Guy L, Bernard-Gallon D. Prostate cancer: The main risk and protective factors-Epigenetic modifications. Ann Endocrinol (Paris). 2015; 76:25-41.

3. Daures M, Ngollo M, Idrissou M, Judes G, Rifaï K, PenaultLlorca F, Bignon YJ, Guy L, Bernard-Gallon D. Soy phytoestrogens on DNA methylation in prostate cancer. Journal of Clinical Epigenetics. 2017; 3:12-14.

4. Ngollo M, Dagdemir A, Karsli-Ceppioglu S, Judes G, Pajon A, Penault-Llorca F, Boiteux JP, Bignon YJ, Guy L, Bernard-Gallon DJ. Epigenetic modifications in prostate cancer. Epigenomics. 2014; 6:415-426.

5. Daures M, Ngollo M, Idrissou M, Judes G, Rifaï K, PenaultLlorca F, Bignon YJ, Guy L, Bernard-Gallon D. Histone methylation in relation with clinical pathological parameters in prostate cancer. Clinics in Oncology. 2017; 2:1274-1275.

6. Chen Z, Wang L, Wang Q, Li W. Histone modifications and chromatin organization in prostate cancer. Epigenomics. 2010; 2:551-560.

7. Kondo Y, Shen L, Cheng AS, Ahmed S, Boumber Y, Charo C, Yamochi T, Urano T, Furukawa K, Kwabi-Addo B, Gold DL, Sekido Y, Huang TH, Issa JP. Gene silencing in cancer by histone $\mathrm{H} 3$ lysine 27 trimethylation independent of promoter DNA methylation. Nat Genet. 2008; 40:741-750.

8. Ngollo M, Dagdemir A, Judes G, Kemeny JL, PenaultLlorca F, Boiteux JP, Lebert A, Bignon YJ, Guy L, BernardGallon D. Epigenetics of prostate cancer: distribution of histone H3K27me3 biomarkers in peri-tumoral tissue. Omics. 2014; 18:207-209.

9. Ngollo M, Lebert A, Dagdemir A, Judes G, KarsliCeppioglu S, Daures M, Kemeny JL, Penault-Llorca F, Boiteux JP, Bignon YJ, Guy L, Bernard-Gallon D. The association between histone 3 lysine 27 trimethylation (H3K27me3) and prostate cancer: relationship with clinicopathological parameters. BMC Cancer. 2014; 14:994.

10. Daures M, Ngollo M, Judes G, Rifai K, Kemeny JL, Penault-Llorca F, Bignon YJ, Guy L, Bernard-Gallon D. The JMJD3 Histone Demethylase and the EZH2 Histone Methyltransferase in Prostate Cancer. Omics. 2016; 20:123-125.

11. Bracken AP, Pasini D, Capra M, Prosperini E, Colli E, Helin K. EZH2 is downstream of the pRB-E2F pathway, 
essential for proliferation and amplified in cancer. EMBO J. 2003; 22:5323-5335.

12. Shiogama S, Yoshiba S, Soga D, Motohashi H, Shintani S. Aberrant expression of EZH2 is associated with pathological findings and P53 alteration. Anticancer Res. 2013; 33:4309-4317.

13. Yang YA, Yu J. EZH2, an epigenetic driver of prostate cancer. Protein Cell. 2013; 4:331-341.

14. Varambally S, Dhanasekaran SM, Zhou M, Barrette TR, Kumar-Sinha C, Sanda MG, Ghosh D, Pienta KJ, Sewalt RG, Otte AP, Rubin MA, Chinnaiyan AM. The polycomb group protein EZH2 is involved in progression of prostate cancer. Nature. 2002; 419:624-629.

15. Xu K, Wu ZJ, Groner AC, He HH, Cai C, Lis RT, Wu X, Stack EC, Loda M, Liu T, Xu H, Cato L, Thornton JE, et al. EZH2 oncogenic activity in castration-resistant prostate cancer cells is Polycomb-independent. Science. 2012; 338:1465-1469.

16. Uchiyama N, Tanaka Y, Kawamoto T. Aristeromycin and DZNeP cause growth inhibition of prostate cancer via induction of mir-26a. Eur J Pharmacol. 2017; 812:138-146.

17. Crea F, Hurt EM, Mathews LA, Cabarcas SM, Sun L, Marquez VE, Danesi R, Farrar WL. Pharmacologic disruption of Polycomb Repressive Complex 2 inhibits tumorigenicity and tumor progression in prostate cancer. Mol Cancer. 2011; 10:40.

18. Ene CI, Edwards L, Riddick G, Baysan M, Woolard K, Kotliarova S, Lai C, Belova G, Cam M, Walling J, Zhou M, Stevenson H, Kim HS, et al. Histone demethylase Jumonji D3 (JMJD3) as a tumor suppressor by regulating p53 protein nuclear stabilization. PLoS One. 2012; 7:e51407.

19. Burchfield JS, Li Q, Wang HY, Wang RF. JMJD3 as an epigenetic regulator in development and disease. Int $\mathrm{J}$ Biochem Cell Biol. 2015; 67:148-157.

20. Xiang Y, Zhu Z, Han G, Lin H, Xu L, Chen CD. JMJD3 is a histone H3K27 demethylase. Cell Res. 2007; 17:850-857.

21. Ramadoss S, Chen X, Wang CY. Histone demethylase KDM6B promotes epithelial-mesenchymal transition. J Biol Chem. 2012; 287:44508-44517.

22. Park WY, Hong BJ, Lee J, Choi C, Kim MY. H3K27 Demethylase JMJD3 Employs the NF-kappaB and BMP Signaling Pathways to Modulate the Tumor Microenvironment and Promote Melanoma Progression and Metastasis. Cancer Res. 2016; 76:161-170.

23. Perrigue PM, Silva ME, Warden CD, Feng NL, Reid MA, Mota DJ, Joseph LP, Tian YI, Glackin CA, Gutova M, Najbauer J, Aboody KS, Barish ME. The histone demethylase jumonji coordinates cellular senescence including secretion of neural stem cell-attracting cytokines. Mol Cancer Res. 2015; 13:636-650.

24. Shen Y, Guo X, Wang Y, Qiu W, Chang Y, Zhang A, Duan X. Expression and significance of histone H3K27 demethylases in renal cell carcinoma. BMC Cancer. 2012; 12:470.
25. Tian C, Deng H, Tang X, Hu H, Liu X, Luo F. [Effect of Jumonji domain-containing protein-3 on the proliferation and migration of lung cancer cell line]. [Article in Chinese]. Sheng Wu Yi Xue Gong Cheng Xue Za Zhi. 2012; 29:514-518.

26. Pereira F, Barbachano A, Silva J, Bonilla F, Campbell MJ, Munoz A, Larriba MJ. KDM6B/JMJD3 histone demethylase is induced by vitamin $\mathrm{D}$ and modulates its effects in colon cancer cells. Hum Mol Genet. 2011; 20:4655-4665.

27. Tokunaga R, Sakamoto Y, Nakagawa S, Miyake K, Izumi D, Kosumi K, Taki K, Higashi T, Imamura Y, Ishimoto T, Iwatsuki M, Baba Y, Miyamoto Y, et al. The Prognostic Significance of Histone Lysine Demethylase JMJD3/ KDM6B in Colorectal Cancer. Ann Surg Oncol. 2016; 23:678-685.

28. Yapp C, Carr AJ, Price A, Oppermann U, Snelling SJ. H3K27me3 demethylases regulate in vitro chondrogenesis and chondrocyte activity in osteoarthritis. Arthritis Res Ther. 2016; 18:158.

29. Ntziachristos P, Tsirigos A, Welstead GG, Trimarchi T, Bakogianni S, Xu L, Loizou E, Holmfeldt L, Strikoudis A, King B, Mullenders J, Becksfort J, Nedjic J, et al. Contrasting roles of histone 3 lysine 27 demethylases in acute lymphoblastic leukaemia. Nature. 2014; 514:513-517.

30. Donas C, Carrasco M, Fritz M, Prado C, Tejon G, OsorioBarrios F, Manriquez V, Reyes P, Pacheco R, Bono MR, Loyola A, Rosemblatt M. The histone demethylase inhibitor GSK-J4 limits inflammation through the induction of a tolerogenic phenotype on DCs. J Autoimmun. 2016; 75:105-117.

31. Hashizume R, Andor N, Ihara Y, Lerner R, Gan H, Chen X, Fang D, Huang X, Tom MW, Ngo V, Solomon D, Mueller $\mathrm{S}$, Paris PL, et al. Pharmacologic inhibition of histone demethylation as a therapy for pediatric brainstem glioma. Nat Med. 2014; 20:1394-1396.

32. Yan N, Xu L, Wu X, Zhang L, Fei X, Cao Y, Zhang F. GSKJ4, an H3K27me3 demethylase inhibitor, effectively suppresses the breast cancer stem cells. Exp Cell Res. 2017; 359:405-414.

33. Ngollo M, Lebert A, Daures M, Judes G, Rifai K, Dubois L, Kemeny JL, Penault-Llorca F, Bignon YJ, Guy L, BernardGallon D. Global analysis of H3K27me3 as an epigenetic marker in prostate cancer progression. BMC Cancer. 2017; 17:261.

34. Epstein JI, Egevad L, Amin MB, Delahunt B, Srigley JR, Humphrey PA. The 2014 International Society of Urological Pathology (ISUP) Consensus Conference on Gleason Grading of Prostatic Carcinoma: Definition of Grading Patterns and Proposal for a New Grading System. Am J Surg Pathol. 2016; 40:244-252.

35. Esteller M, Herman JG. Generating mutations but providing chemosensitivity: the role of O6-methylguanine DNA methyltransferase in human cancer. Oncogene. 2004; 23:1-8. 
36. Mishra DK, Chen Z, Wu Y, Sarkissyan M, Koeffler HP, Vadgama JV. Global methylation pattern of genes in androgen-sensitive and androgen-independent prostate cancer cells. Mol Cancer Ther. 2010; 9:33-45.

37. Maruyama R, Toyooka S, Toyooka KO, Virmani AK, Zochbauer-Muller S, Farinas AJ, Minna JD, McConnell J, Frenkel EP, Gazdar AF. Aberrant promoter methylation profile of prostate cancers and its relationship to clinicopathological features. Clin Cancer Res. 2002; 8:514-519.

38. Zhang Z, Xin S, Gao M, Cai Y. Promoter hypermethylation of MGMT gene may contribute to the pathogenesis of gastric cancer: A PRISMA-compliant meta-analysis. Medicine (Baltimore). 2017; 96:e6708.

39. Munkley J, Livermore K, Rajan P, Elliott DJ. RNA splicing and splicing regulator changes in prostate cancer pathology. Hum Genet. 2017; 136:1143-1154.

40. Xu W, Huang H, Yu L, Cao L. Meta-analysis of gene expression profiles indicates genes in spliceosome pathway are up-regulated in hepatocellular carcinoma (HCC). Med Oncol. 2015; 32:96.

41. Perez-Ramirez M, Hernandez-Jimenez AJ, GuerreroGuerrero A, Siordia-Reyes AG, Hernandez-Caballero ME, Garcia-Mendez A, Chico-Ponce de Leon F, SalamancaGomez FA, Garcia-Hernandez N. Pediatric pineal germinomas: Epigenetic and genomic approach. Clin Neurol Neurosurg. 2017; 152:45-51.

42. Liu T, Sun H, Zhu D, Dong X, Liu F, Liang X, Chen C, Shao B, Wang M, Wang Y, Sun B. TRA2A Promoted Paclitaxel Resistance and Tumor Progression in TripleNegative Breast Cancers via Regulating Alternative Splicing. Mol Cancer Ther. 2017; 16:1377-1388.

43. Yang S, Chen L, Chan DW, Li QK, Zhang H. Protein signatures of molecular pathways in non-small cell lung carcinoma (NSCLC): comparison of glycoproteomics and global proteomics. Clin Proteomics. 2017; 14:31.

44. Armstrong RN, Steeples V, Singh S, Sanchi A, Boultwood J, Pellagatti A. Splicing factor mutations in the myelodysplastic syndromes: target genes and therapeutic approaches. Adv Biol Regul. 2018; 67:13-29.

45. Houles T, Roux PP. Defining the role of the RSK isoforms in cancer. Semin Cancer Biol. 2018; 48:53-61.

46. Clark DE, Errington TM, Smith JA, Frierson HF Jr, Weber MJ, Lannigan DA. The serine/threonine protein kinase, p90 ribosomal S6 kinase, is an important regulator of prostate cancer cell proliferation. Cancer Res. 2005; 65:3108-3116.

47. Bignone PA, Lee KY, Liu Y, Emilion G, Finch J, Soosay AE, Charnock FM, Beck S, Dunham I, Mungall AJ, Ganesan TS. RPS6KA2, a putative tumour suppressor gene at $6 \mathrm{q} 27$ in sporadic epithelial ovarian cancer. Oncogene. 2007; 26:683-700.

48. Zhao H, Martin TA, Davies EL, Ruge F, Yu H, Zhang Y, Teng XU, Jiang WG. The Clinical Implications of RSK1-3 in Human Breast Cancer. Anticancer Res. 2016; 36:1267-1274.

49. Idrissou M, Daures $M$, Jemia AB, Judes $G$, Rifai K, Penault-Llorca F, Bignon YJ, Guy L, Bernard-Gallon D. EZH2 Histone Methyltransferase and JMJD3 Histone Demethylase Implications in Prostate Cancer. Omics. 2017; 21:751-753.

50. Vlietstra RJ, van Alewijk DC, Hermans KG, van Steenbrugge GJ, Trapman J. Frequent inactivation of PTEN in prostate cancer cell lines and xenografts. Cancer Res. 1998; 58:2720-2723.

51. Taylor BS, Schultz N, Hieronymus H, Gopalan A, Xiao Y, Carver BS, Arora VK, Kaushik P, Cerami E, Reva B, Antipin Y, Mitsiades N, Landers $\mathrm{T}$, et al. Integrative genomic profiling of human prostate cancer. Cancer Cell. 2010; 18:11-22.

52. Lu W, Liu S, Li B, Xie Y, Izban MG, Ballard BR, Sathyanarayana SA, Adunyah SE, Matusik RJ, Chen Z. SKP2 loss destabilizes EZH2 by promoting TRAF6mediated ubiquitination to suppress prostate cancer. Oncogene. 2017; 36:1364-1373.

53. Lei $\mathrm{X}, \mathrm{Xu}$ JF, Chang RM, Fang F, Zuo CH, Yang LY. JARID2 promotes invasion and metastasis of hepatocellular carcinoma by facilitating epithelial-mesenchymal transition through PTEN/AKT signaling. Oncotarget. 2016; 7:4026640284. https://doi.org/10.18632/oncotarget.9733.

54. Ha SD, Cho W, Kim SO. HDAC8 Prevents Anthrax Lethal Toxin-induced Cell Cycle Arrest through Silencing PTEN in Human Monocytic THP-1 Cells. Toxins (Basel). 2017; 9.

55. Morozov VM, Li Y, Clowers MM, Ishov AM. Inhibitor of H3K27 demethylase JMJD3/UTX GSK-J4 is a potential therapeutic option for castration resistant prostate cancer. Oncotarget. 2017; 8:62131-62142. https://doi.org/10.18632/ oncotarget.19100. 